\title{
䒘ミののシートレビこー
}

\section{固体パラ水素の高分解能振動励起スペクトル 〜振動励起子の非局在化とスペクトルの関係〜}

\author{
香月 浩 之 \\ チューリヒ大学物理化学研究科, \\ Winterthurerstrasse 190, CH-8057 Zuerich, Switzerland
}

（2003年11月10日＼cjkstart受理）

High-Resolution Spectroscopy of Vibrational Transitions of Solid Parahydrogen $\sim$ relation between the delocalization of exciton and spectrum

Hiroyuki KATSUKI

Physical Chemistry Institute, University of Zuerich, Winterthurerstrasse 190, CH-8057 Zuerich, Switzerland

(Received November 10, 2003)

\section{1.はじめに}

\section{1 固体の振動励起状態}

凝縮系中での赤外吸収分光では通常, 様々な線幅広がり の要因によって，非常にブロードなスペクトルしか観測す ることができない，例えば固体中では，気相中と比べて分 子間距離が小さいため，分子間相互作用に基づく緩和過程 が重要となる。この結果励起状態の寿命は短くなり，均一 線幅は増大する。また，不純物や結晶のひずみ等個々の分 子の周困の環境は異なっており，これらは不均一線幅をも たらす。さらに, 凝縮系固有の線幅要因である振動励起状 態のバンド形成も吸收線の線幅広がりの一因となる。

バンド形成の最も単純な例として 2 分子系を考える。 分子間に相互作用がない場合には振動励起状熊は縮退して おり，励起状態の固有関数として各分子の振動波動関数 $\phi_{1}, \phi_{2}$ をそのまま用いることができる.しかし，振動励起 子間の相互作用 $V$ が無視できない場合には縮退は破れ， 固有関数としては $\phi_{1} \pm \phi_{2}$ を用いる必要がある。この場 合，振動励起子の分布も両分子上にまたがったものにな る，つまり，励起状態の非局在化である，以下ではこのよ うな相互作用を vibron hopping と呼ぶことにする。対象 が無数の分子からなる分子性結晶では, 無数の縮退した状 態間の hopping 相互作用の結果，振動励起状態はブロー
ドなバンド構造をとり, 励起状態の波動関数は結晶中に非 局在化することになる.

以上のように様々な要因が重なり合っているため, 固体 のブロードな吸収スペクトルから分子間の相互作用に関す る情報を導き, 詳しい議論を行うことは一般に困難である と言える。

\section{2 固体水素の分光的特徵}

固体水素は最もシンプルな分子性結晶であるが，分子間 相互作用の弱さと分子の軽さのために，他の固体とは大き く異なった特徴を持っている1)。例えば，各水素分子は固 体中に捈いてもほぼ自由回転しており回転量子数が定義で きる，特に，極低温下でのパラ水素はほぼ全て $J=0$ の状 態にあるため, その回転波動関数は等方的となり, 固体パ ラ水素はいわば「分子内振動の自由度を持った希ガス結 晶」のように振る舞うことが知られている2).

さらに固体パラ水素においては, 均一及び不均一な線幅 広がりの影響が非常に小さく，固体中であるにもかかわら ず，気相に抢けるDoppler 極限をもしのぐほどの幅の狭 い遷移が報告されている3)。均一幅が小さいことは次のよ うに説明される。水素分子の振動周波数, 回転定数が $4401 \mathrm{~cm}^{-1}, 61 \mathrm{~cm}^{-1}$ と非常に大きいため, 励起状態が緩 和するときに周囲の熱浴とやりとりするエネルギーも非常 に大きなものとなる。固体水素のデバイ温度は $120 \mathrm{~K}$ 
$\left(83.4 \mathrm{~cm}^{-1}\right)$ であるため ${ }^{4)}$ ，水素分子の分子内振動のエネ ルギーが熱浴に拡散する場合には熱浴との高次の非調和相 互作用が必要となる，その上うな相互作用はとても弱いた め, 固体パラ水素中の励起状態のポピュレーション緩和は 非常に遅く，その結果スペクトル線幅は鋭くなる。一方， 不均一幅が小さい理由は, 結晶中での水素分子のフォノ の零点振動の振幅が大きく，結晶にひずみや欠損が生じに くいためである ${ }^{5)}$. vibron hopping 相互作用による振動バ ンド幅についても，倍音，三倍音，上なるにつれて後述す るようにおよそ2桁ずつ小さくなっていく.

以上の理由から，他の凝縮系ではブロードな線幅に埋も れて観測できない固体の振動励起状態における励起子間相 互作用の影響を，固体パラ水素中では特に倍音領域の高分 解能スペクトル測定によって直接スペクトルの分裂として 観測する事ができる。

本稿では, 固体パラ水素の $\mathrm{Q}_{\mathrm{n}}(0)$ 振動吸収遷移 $(v=n$ $\leftarrow 0, J=0 \leftarrow 0)$ の $n=1,2,3$ の各場合について得られたス ペクトルに基づき，振動励起エネルギーが固体中でどのよ うな状態で分布しているかについてモデル計算から得られ た結果を紹介寸る6-8)

ここで本研究で測定した $\mathrm{Q}_{\mathrm{n}}(0)$ 吸収遷移のメカニズム について説明して扔く.J=0のパラ水素分子は等方的な 回転波動関数を持つため, 孤立状態にある分子では遷移 モーメントはゼロであり， $\mathrm{Q}_{\mathrm{n}}(0)$ 振動吸収遷移は禁制であ る.しかしながら固体パラ水素結晶では常に微少量ながら 不純物として $J=1$ 状態を占めるオルト水素が存在する. このオルト水素は永久四重極子モーメントを持っているた め，その周囲にあるパラ水素分子に誘起双極子モーメント を生じさせる，このようなオルト・パラ対が固体中に存在 していると, レーザーの電場と誘起双極子モーメントが相 互作用し，その結果パラ水素の振動吸収遷移が観測され る. オルト水素は固体パラ水素内に扔いて, レーザ一光と の相互作用を引き起こす「アンテナ」として働くと考えて もらえばよい。

\section{2. 実験}

\section{1 固体水素の作成}

通常の水素ガスはオルト：パラ比が $3: 1$ で混在してい る。このノ一マル水素を $14.0 \mathrm{~K}$ に扮いて触媒中（ $\mathrm{Fe}$ $\left.(\mathrm{OH})_{3}\right)$ を通過させることであらかじめパラ水素に変換し て抢く，パラ水素とオルト水素間の相互变換は磁気的な相 互作用がない限り室温でも進行が非常に遅いことが知られ ている，以下の実験に打ける結晶中の才ルト水素濃度は $\mathrm{Q}_{1}(0), \mathrm{Q}_{2}(0)$ では0.01\%以下であり, $\mathrm{Q}_{3}(0)$ では $0.1 \%$ 以 下である。

固体水素の結晶は, 液体へリウムクライオスタットに固 定された銅製のセルに室温のパラ水素ガスを流し込むこと で気体から直接成長させる。この結果得られる結晶はマク
ロなサイズで結晶軸方向を定義できる六方最密構造をもっ

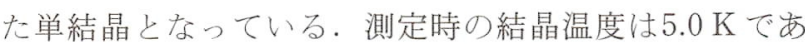
る.

\section{2 測定手法}

固体パラ水素の $\mathrm{Q}_{\mathrm{n}}(0)$ 遷移周波数は $n=1,2,3$ のそれ ぞれについて4153,8070, $11758 \mathrm{~cm}^{-1}$ である。 Q Q $_{1}(0)$ 遷移 についてはWelsh らによってはじめて赤外吸収が観測さ れ ${ }^{9)}$, Poll らによるバンド計算 ${ }^{10)}$ は実験結果に良く一致し ている、 $\mathrm{Q}_{3}(0)$ 遷移については Dickson らによる高分解能 スペクトルが報告されているが11,12)， $Q_{2}(0)$ 遷移に関して は Mengel らによる低分解能スペクトルの報告があるだけ であり ${ }^{13)}$ ，今回高分解能の $\mathrm{Q}_{2}(0)$ スペクトルを初めて観 測した。またこの高分解能 $\mathrm{Q}_{2}(0)$ スペクトルと比較する ために，より高い分解能で $\mathrm{Q}_{1}(0), \mathrm{Q}_{3}(0)$ 遷移の測定を行 った。

$\mathrm{Q}_{1}(0)$ 遷移の観測には FTIR 分光器 (Bruker HR-120) を用い $\mathrm{Q}_{3}(0)$ 遷移の観測には CW レーザー（Ti-Sapphire） を用いた。遷移周波数が $8000 \mathrm{~cm}^{-1}$ 付近の $\mathrm{Q}_{2}(0)$ 遷移に 関しては，この周波数帯域の適当なレーザー光源が存在し ないため, 2 台のCWレーザー(Ti-Sapphire 及び色素) の差周波発振老用いた14).

$\mathrm{Q}_{2}(0)$ 測定の際の装置の概略を図 1 に示す。変調に tone-burst 法 ${ }^{15)}$ と呼ばれる強度変調を用いているため, 吸 收は二次微分形で得られる。この測定における分解能は 3 $\mathrm{MHz}$ である.

測定されたスペクトルを図 2 に示す。 $\mathrm{Q}_{1}(0)$ 遷移（図 2 (a)）は線形が非対称で $3 \mathrm{~cm}^{-1}$ の幅を持ったブロードな 吸収スペクトルとして観測され，高分解能に抢ける測定で も微細構造は得ることができなかった。このことから，v $=1$ の振動励起状態は通常の固体同様バンド構造を形成し ていると考えられる ${ }^{10)}$ 。一方, $\mathrm{Q}_{2}(0)$ 遷移ではスペクトル の様子は全く異なり，0.3 $\mathrm{cm}^{-1}$ 間隔で分裂した 2 つ吸 収（図 $2(\mathrm{c})$ ) がみられ、これらがさらに $20 \mathrm{MHz}$ 程度の 線幅を持った微細な構造を持っている.これらの線幅の狭

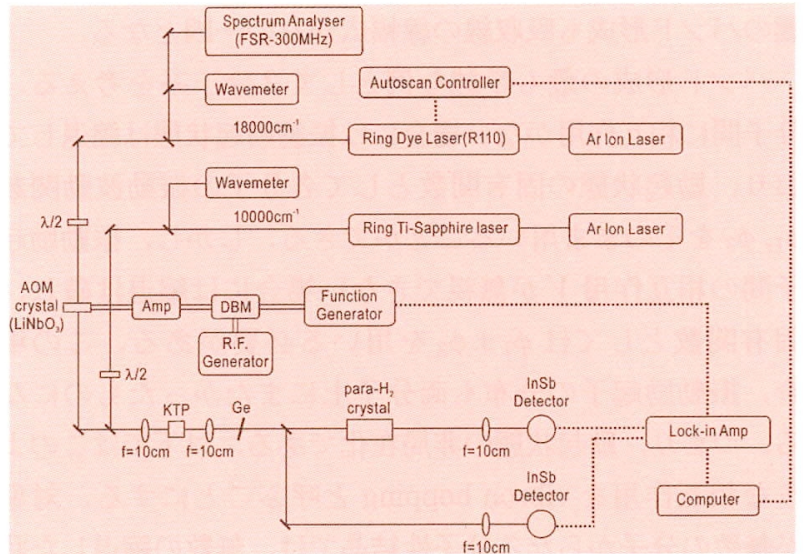

図 $1 \mathrm{Q}_{2}(0)$ 遷移観測用の高分解能差周波レーザー装置図. 
$Q_{1}(0)$

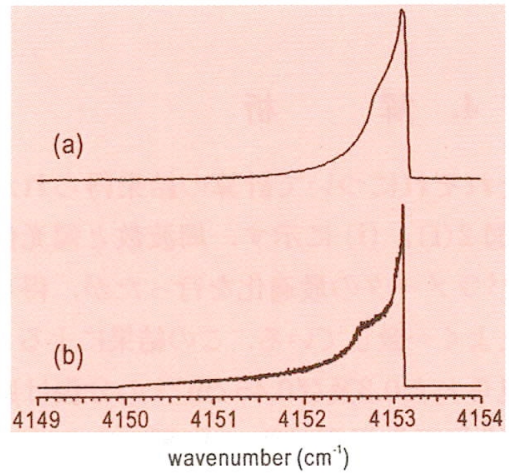

$Q_{2}(0)$

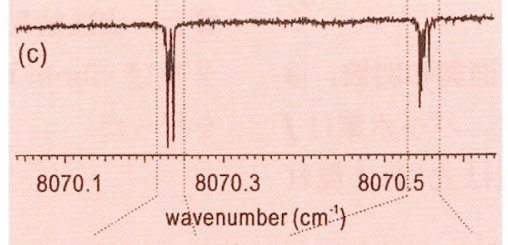

(d)

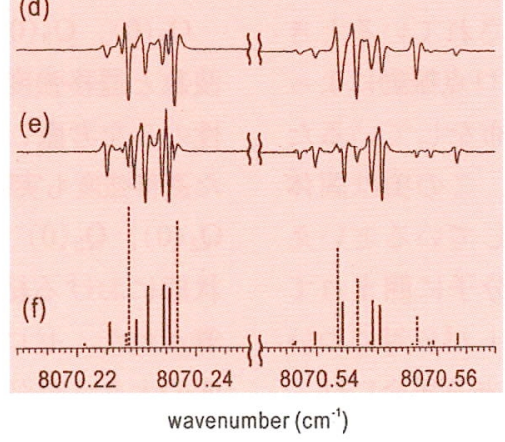

$Q_{3}(0)$

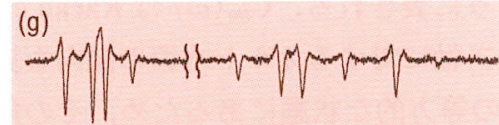

(h)
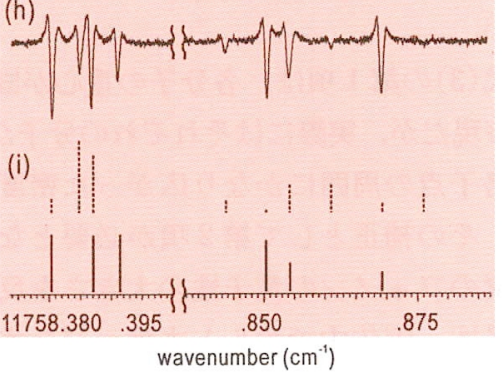

図 $2 \mathrm{Q}_{\mathrm{n}}(0)$ 吸収スペクトル。 (a) FTIR 分光器による $\mathrm{Q}_{1}(0)$ 吸収スペクトル, (b) Bloch 関数を用いて計算した励起状 態バンド密度，(c) $\mathrm{Q}_{2}(0)$ スペクトル，(d) parallel 偏光高分解能スペクトル，(e) perpendicular 偏光高分解能ス ペクトル，(f) $\mathrm{Q}_{2}(0)$ 遷移の計算周波数及び強度破線は parallel 遷移, 実線は perpendicular 遷移, (g) $\mathrm{Q}_{3}(0)$ スペ クトル (parallel 遷移), (h) $\mathrm{Q}_{3}(0)$ スペクトル (perpendicular 遷移), (i) $\mathrm{Q}_{3}(0)$ 遷移の計算周波数及び強度破線は parallel 遷移実線は perpendicular 遷移.

い吸収線はすべて, 遷移強度に明確な偏光依存性があるこ とも確認された（図 $2(\mathrm{~d}),(\mathrm{e}))$.

$\mathrm{Q}_{3}(0)$ 遷移でも, $0.45 \mathrm{~cm}^{-1}$ の間隔で分裂した 2 ヶ所に 微細な吸収線が観測された（図 $2(\mathrm{~g}),(\mathrm{h}))$ 。しかし, 観 測された吸收の本数は $\mathrm{Q}_{2}(0)$ 上りも少ない。 $\mathrm{Q}_{3}(0)$ 遷移 の線幅は $30 \mathrm{MHz}$ と $\mathrm{Q}_{2}(0)$ よりも大きな值たが，この理由 は遷移強度をかせぐためにオルト水素の濃度を増した結 果, 個々のパラ水素分子の周囲のオルト水素の分布に変化 が生じ，不均一幅が増大したためである.

\section{3.モデルハミルトニアンを用いた 遷移エネルギー, 遷移強度の計算}

ここでは, 実験で得られたスペクトルを比較的単純な八 ミルトニアンを用いて記述する手法について紹介する。 ス ペースの都合上計算の詳細については文献6-8) を参照して 頂きたい，固体中の相互作用の要因としては水素分子間の 分散力相互作用, そしてオルト水素の四重極モーメントに よる誘起相互作用が挙げられる. 以下の取り扱いでは分子 の配向に依存する結晶場相互作用, 分子の振動励起子間の 相互作用である vibron hopping 相互作用に分けて考慮す

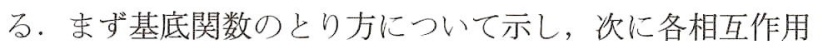
について具体的に説明する.

\section{1 基底関数系}

上述したように, $\mathrm{Q}_{\mathrm{n}}(0)$ 遷移はオルト水素とパラ水素の ペアがあっでばめて起こりうる遷移である。このため, 固体水素表表基底関数としては，1個のオルト水素々そ の周囲を取り囲むパラ水素分子の波動関数の直積を用い
る. オルト水素は $J=1$, パラ水素は $J=0$ の状態のみを考 慮すればいいので振動基底状態は

$$
|m\rangle_{g r}=|v=0, J=1, M=m\rangle \prod_{i}^{N}\left|v_{i}=0, J=0, M=0\right\rangle
$$

と表せる. $m$ はオルト水素の方位量子数であり $m=0, \pm 1$ をとる。振動励起状態 $(v=n)$ の基底系は

$$
\begin{aligned}
& \left|v_{i}=n, m^{\prime}\right\rangle_{e x}=\left|v=0, J=1, M=m^{\prime}\right\rangle \\
& \left|v_{i}=n, J=0, M=0\right\rangle \prod_{j \neq i}^{N}\left|v_{j}=0, J=0, M=0\right\rangle
\end{aligned}
$$

と表すことができる. 振動励起状態の基底として，1 分子 上に振動励起状態が完全に局在化した状態を用いているこ とに注意して欲しい.

$N$ は振動励起状態が広がると考えられるオルト水素周 りのパラ水素分子の数を表す。実際の計算に招いてはオル 卜水素から 4 番目の近接分子までに相当する38個のパラ 水素分子を考慮した. もし振動励起状態が十分に非局在化 しているならば,ささら多数のパラ水素を考慮する必要が あるが, 後に示すように $\mathrm{Q}_{2}(0), \mathrm{Q}_{3}(0)$ の場合にはこの基 底で十分である。

\section{2 結晶場相互作用}

まず，オルト水素とパラ水素のペアを取り出して考え る.オルト水素の配向に依存するポテンシャルの最低次の 項は 


$$
V=B_{0} C_{20}(\omega)+B_{2}\left[C_{22}(\omega)+C_{2-2}(\omega)\right]
$$

のように表される. $C_{l m}(\omega)$ は Racah の球面調和関数, $\omega$ はペア軸に対するオルト水素の配向を表す。パラ水素はJ $=0$ の等方的な状態にあるため, その角度は式 (3)に現れ ない.

式(3)の第 1 項は，各分子の重心が固定されているとき の表現だが，実際にはそれぞれの分子がゼロ点振動によっ て格子点の周囲にかなり広がった密度分布をしているた め，その補正として第 2 項が必要となる，この項は固体 水素のフォノンの量子性の大きさを反映しているといえ る $^{1,2,16)}$. 固体中でオルト水素がパラ水素分子に囲まれて いるような状態では式(3)をすべてのオルトパラ対につい て和をとる必要がある。振動の基底状態にある場合には, 結晶の対称性から

$$
V_{g r}=\sum_{\text {all pairs }} V=\varepsilon C_{20}(\Omega)
$$

となる， $\Omega$ は結晶軸に対するオルト水素の配向である. 各パラ水素分子との相互作用が互いに打ち消しあう寄与を するため， $\varepsilon$ の大きさは $0.01 \mathrm{~cm}^{-1}$ 程度と非常に小さい.

一方, パラ水素の振動励起状態では分子の分極率が変化 するため，ペアポテンシャルの大きさも変化する．この影 響は $V_{g r}$ に対する付加項として

$$
V_{e x}=V_{g r}+\Delta B_{0} C_{20}(\omega)+\Delta B_{2}\left[C_{22}(\omega)+C_{2-2}(\omega)\right]
$$

\section{のように表される。}

\section{3 vibron hopping 相互作用}

これまで，振動励起状態は 1 つの分子上に局在してい ると考えてきたが，実際には近接するパラ水素分子間で振 動励起状態の hopping が起こる. 具体的には, 分散力相 互作用のうち，パラ水素の分子内振動モードに依存する相 互作用によって，振動励起状態の波動関数が非局在化す る. 2 つのパラ水素分子をそれぞれ $i, j$ とし，各分子の分 子内振動モードを $q_{i}, q_{j}$ とすると, hopping 相互作用 $V_{\text {hop }}$ は

$$
V_{\text {hop }}=\sum_{m, n} \frac{1}{m ! n !} \frac{\partial^{m+n} V}{\partial^{m} q_{i} \partial^{n} q_{j}} q_{i}^{m} q_{j}^{n}=\sum_{m, n} V_{m n}
$$

と表される. $v=2$ 状態がホップするには最低次の寄与と して $V_{22}$ が必要であり， $v=3$ 状態のホップには $V_{33}$ が必 要となる．実際の計算に際して，3.1節で定義した励起状 態の基底表現を用いてホッピングパラメータ $\sigma_{2 n}$ を最近接 パラ水素間の行列要素

$$
\sigma_{2 n}=\left\langle v_{i}=n, m^{\prime}\left|V_{n n}\right| v_{j}=n, m^{\prime}\right\rangle
$$

と定義する。最近接以外のペアについては相互作用は $R-6$ に比例して減少すると考えられる.
これらの行列要素を用いて，遷移周波数，遷移強度を計 算し，実験結果にあうように式(4)，(5)の結晶場パラメ一 タ及び vibron hopping 相互作用パラメータ $\sigma_{2 n}$ の最適化 を行った。

\section{4. 解 析}

$\mathrm{Q}_{2}(0), \mathrm{Q}_{3}(0)$ それぞれについて計算の結果得られた周 波数と遷移強度を図 $2(\mathrm{f})$ ，（i）に示す．周波数と偏光依存 性のみを考慮してパラメータの最適化を行ったが，得られ た遷移強度も実験とよく一致している。この結果によると， $\mathrm{Q}_{2}(0), \mathrm{Q}_{3}(0)$ で見られた 0.3 及び $0.45 \mathrm{~cm}^{-1}$ の分裂は励起 状態における結晶場相互作用項 $\Delta B_{0}$ の影響であることが 導かれた。ゼ口点振動由来の補正項 $\Delta B_{2}$ は $\Delta B_{0}$ の $2 \%$ 程 度の大きさだが，実験で得られたスペクトルの本数を説明 するためには無視できない項である7'.

Vibron hopping 相互作用に関しては， $Q_{2}(0)$ では振動 励起状態のホッピングパラメータとして $\sigma_{4}=-0.0038$ $\mathrm{cm}^{-1}$ という值が定まったが， $\mathrm{Q}_{3}(0)$ 遷移ではホッピング による状態分裂は実験精度内では観測されなかった（|$\sigma_{6} \mid$ $\left.<0.0001 \mathrm{~cm}^{-1}\right)$. ホッピングが無視できる場合, $\mathrm{Q}_{2}(0)$ の スペクトルは $\mathrm{Q}_{3}(0)$ と全く同じ構造を示すはずであり， $\mathrm{Q}_{2}(0)$ 遷移で観測された余分な分裂はホッピングによる付 加的な分裂であると結論される。

ここで，もう一度 $\mathrm{Q}_{1}(0)$ 遷移について言及しておく。 図 2 (a)のスペクトルから，v=1 励起状態は結晶内でかな り非局在化していると予想される。このような系の記述に は，3.1節で定義したような基底関数系は適切ではなく， むしろ Bloch 関数を用いた方が都合がよい。図 1(b)に結 晶場相互作用を考慮せず，ホッピングパラメータ $\sigma_{2}=-$ $0.19 \mathrm{~cm}^{-1}$ と仮定して計算した振動励起状態のバンドの状 態密度を示した．遷移強度を考慮していないので実測のス ペクトルとの直接の比較は出来ないが，両者は非常によく 似ており，v=1 状態はBloch 波動関数でうまく記述され ると言うことが出来る.

以上をまとめると，固体水素の $\mathrm{Q}_{\mathrm{n}}(0)$ 遷移に沶いて は，ホッピング相互作用とオルト水素の異方性に基づく結 晶場相互作用の大きさの大小関係によって励起状態の非局 在の度合いが決まると考えられる。

図 3 (a)に結晶場相互作用の結果生じる振動励起状態の 準位分裂を示す。オルト水素の最近接 $(\mathrm{NN})$ と第二近接 (NNN) 位置に振動励起したパラ水素がある場合のエネル ギー準位の差を $\Delta E$ を考えると，この值はほぼ $\Delta B_{0}$ によ り決をる。この図から vibron hopping パラメータ $\sigma_{2 n}$ が $\Delta E$ 程度かそれより大きく， NN から $\mathrm{NNN}$ の非局在化 が起こった場合，同時に結晶全体への非局在化が起こるこ とがわかる。

励起状態の振動量子数と $\Delta E$ との関係は次のように見積 もられる。結晶場相互作用のパラメータ $\Delta B_{0}$ は振動励起 


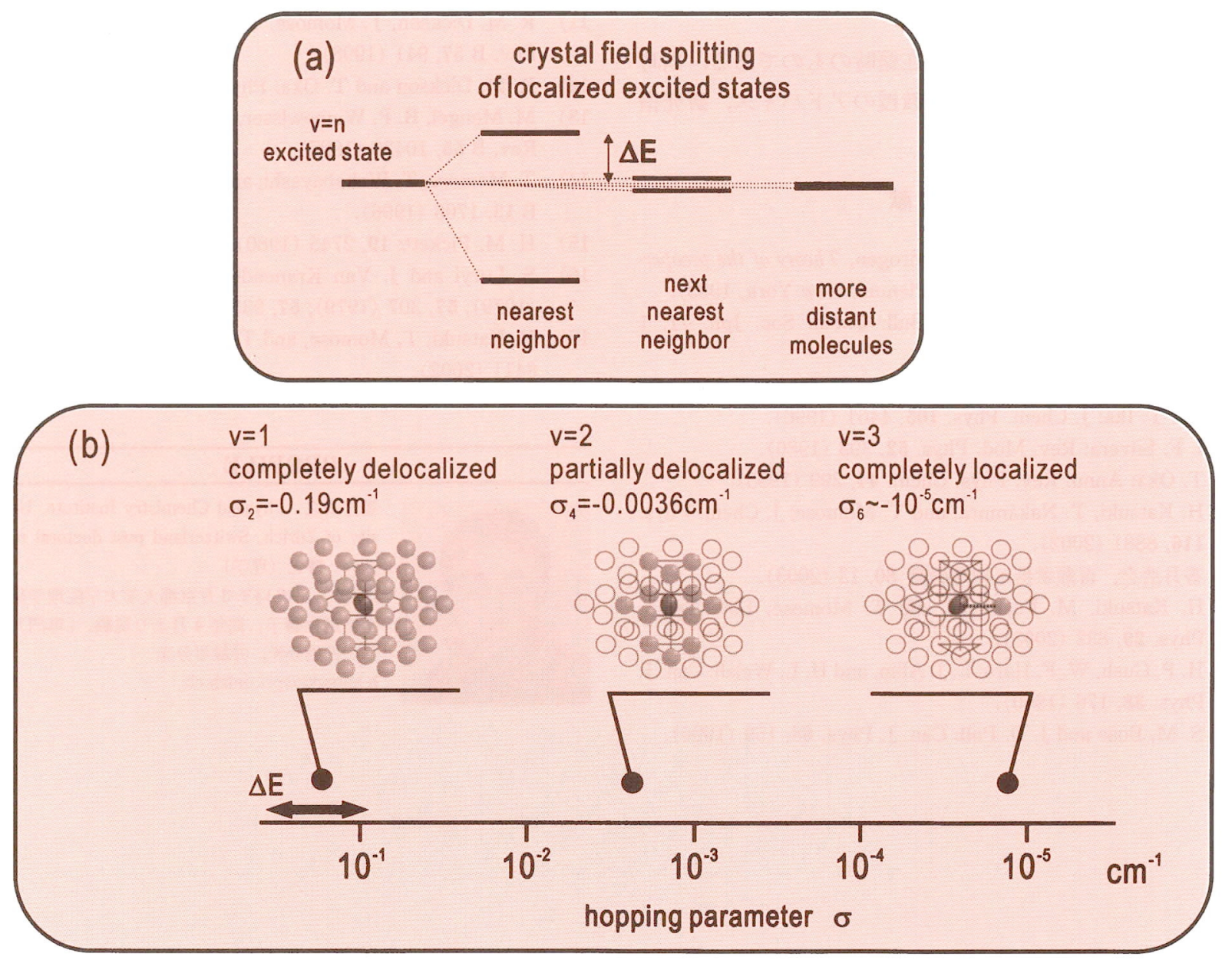

図 3 (a)結晶場相互作用によるオルト・パラ水素対の $Q_{n}(0)$ 励起状態の分裂.オルト水素の NN (Nearest Neighbour) パラ水素が励起された場合と NNN (Next Nearest Neighbour) が励起された場合でのエネルギー準位の差を $\Delta E$ と定義する。（b) $\Delta E$ とホッピソグパラメータ $\sigma$ の大小関係と $\mathrm{Q}_{\mathrm{n}}(0)$ 励起状態の非局在の度合いの関係. $v=1,2$, 3 の各場合で $\Delta E$ の大きさがほぼ一定である一方， $\sigma$ は約 2 桁ずつ変化する.

状態と基底状態に㧍ける分極率の差 $\left(\alpha_{n}-\alpha_{0}\right)$ にほぼ比例 する．例えば， $v=1$ と $v=3$ の状態での分極率の変化 $\left(\alpha_{3}\right.$ $\left.-\alpha_{0}\right) /\left(\alpha_{1}-\alpha_{0}\right)$ は3.1程度の值上なる。この結果, $\Delta E$ の才一 ダーは終状態の振動量子数によらずほぼ $0.1 \mathrm{~cm}^{-1}$ 程度の 值になる。一方 vibron hopping パラメータ $\sigma_{2 n}$ の大きさ に関しては执よそ $\sigma_{2 n+2} / \sigma_{2 n}=0.01 の$ 関係が見積もられて いる11)。つまり, $v=1$ と $v=3$ の状態で $10^{4}$ という大きな 変化が生じる.

$\Delta E$ と $\sigma_{2 n}$ の相対的な大きさと振動励起状態の非局在性 の関係を図 $3(\mathrm{~b})$ に示す。 $v=1$ 状態では $\Delta E \sim \sigma_{2}$ となるた めに，NNから NNN，さらに結晶全体への励起状態の非 局在化が起こりうるが， $v=2$ では $\Delta E>\sigma_{4}$ のため励起状 態はオルト水素の最近接の位置にある12個のパラ水素の 間での久非局在化を起こす。さらにv=3では，実験精度 範囲で $\Delta E \gg \sigma_{6} \sim 0$ となるため，ホッピングの影響はもは や無視でき，結晶場分裂した 1 つ準位に振動励起が局 在していると考えることが出来る.
5. とめ

固体パラ水素の持つ分光上の利点を生かし, 凝縮相中の 多体系に扮ける振動励起の非局在性を議論した。特に興昧 深いのは $\mathrm{Q}_{2}(0)$ 遷移の場合であり, この場合結晶場相互 作用, vibron hopping 相互作用の影響がどちらも直接観 測され，固体中でのバンド形成の初段階ともいえる状態に あることが示された。また，結晶場相互作用における量子 的なゼロ点振動の影響 $\left(\Delta B_{2}\right)$ を $\mathrm{Q}_{2}(0), \mathrm{Q}_{3}(0)$ の実験に 招いて直接観測することが出来た。

ここで述べたような高分解能スペクトルの測定は，他の 固体では線幅の広がりの影響で一般に難しい。しかし固体 水素中に単離した分子のクラスター17)や，分子数100個程 度からなる小さな気相クラスターの振動励起であれば，同 様に高分解能スペクトルの観測も可能であると思われる。 このような系に扫ける振動励起エネルギーの分布との比較 が出来れば非常に興味深い. 


\section{謝辞}

以上の研究は京都大学大学院在籍時のものである, 当時 の指導教官であった百瀬孝昌助教授のアドバイス，研究指 導に感謝します。

\section{参考文献}

1) J. Van Kranendonk: Solid Hydrogen, Theory of the prooperties of solid $H_{2}, H D$, and $D_{2}$ (Plenum, New York, 1983).

2) T. Momose and T. Shida: Bull. Chem. Soc. Jpn. 71, 1 (1998).

3) D. P. Weliky, K. E. Kerr, T. J. Byers, Y. Zhang, T. Momose, and T. Ika: J. Chem. Phys. 105, 4461 (1996).

4) I. F. Silvera: Rev. Mod. Phys. 52, 393 (1980).

5) T. Oka: Annu. Rev. Phys. Chem. 44, 299 (1993).

6) H. Katsuki, T. Nakamura, and T. Momose: J. Chem. Phys. 116, 8881 (2002).

7) 香月浩之, 百瀬孝昌：物性研究 80, 13 (2003).

8) H. Katsuki, M. Fushitani, and T. Momose: Low Temp. Phys. 29, 832 (2003).

9) H. P. Gush, W. F. Hare, E. J. Allin, and H. L. Welsh: Can. J. Phys. 38, 176 (1960).

10) S. M. Bose and J. D. Poll: Can. J. Phys. 68, 159 (1990).
11) R. M. Dickson, T. Momose, T. J. Byers, and T. Oka: Phys. Rev. B 57, 941 (1998).

12) R. M. Dickson and T. Oka: Phys. Rev. B 57, 950 (1998).

13) M. Mengel, B. P. Winnewisser, and M. Winnewisser: Phys. Rev. B 55, 10420 (1997).

14) T. Momose, T. Wakabayashi, and T. Shida: J. Opt. Soc. Am. B 13, 1706 (1996).

15) H. M. Pickett: 19, 2745 (1980).

16) S. Luryi and J. Van Kranendonk: Can. J. Phys. 57, 136 (1979); 57, 307 (1979); 57, 933 (1979).

17) H. Katsuki, T. Momose, and T. Shida: J. Chem. Phys. 116 $8411(2002)$

\section{PROFILE}

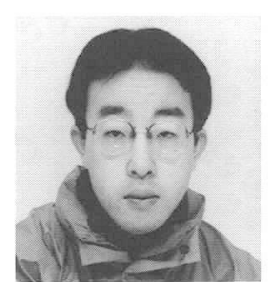

香月浩之 Physical Chemistry Institute, University of Zürich, Switzerland post doctoral researcher 博士 (理学)

[略歴〕平成 13 年 3 月京都大学大学院理学研究科 博士課程修了, 同年 4 月上り現職. [專門〕凝縮 系の振動分光, 非線形分光

h.katsuki@pci.unizh.ch 